\title{
'Een warm hart en een koel hoofd'. Pieter Halting over wetenschap, de natie en de vooruitgang
}

\section{BERT THEUNISSEN}

Pieter Harting is voor wetenschapshistorici een wat ongrijpbare figuur 1. Meestal wordt hij in één adem genoemd met de chemicus G. J. Mulder, de meteoroloog C. H. D. Buys Ballot en de fysioloog F. C. Donders. Gezamenlijk stonden deze Utrechtse hoogleraren in de jaren 1840 aan de basis van de opbloei van de natuurwetenschappen in Nederland, die zijn hoogtepunt zou vinden in het 'tweede gouden tijdperk' van de late negentiende eeuw ${ }^{2}$. Mulder, Buys Ballot en Donders hebben als natuuronderzoekers een duidelijk profiel. Buys Ballot was een van de pioniers van de meteorologie, Donders maakte furore als oogarts en Mulder voerde baanbrekende vernieuwingen door in het chemisch onderwijs. Hartings naam is minder aan een belangrijke innovatie of aan bijzondere onderzoeksprestaties verbonden. Of we moeten hierbij denken aan zijn bijdragen aan de herintroductie van de microscoop in het biologisch onderzoek. Maar zijn onmiskenbare verdiensten in deze hebben meer belangstelling voor zijn instrumenten uitgelokt — van de zijde van specialisten in de geschiedenis van het wetenschappelijk instrument - dan voor hemzelf ${ }^{3}$.

De microscopische studies maken bovendien niet de hoofdmoot van Hartings activiteiten uit. Zijn werk was uitermate breed georiënteerd en kent geen echte hoogtepunten in conventionele zin. Het enthousiasme om zijn bezigheden omvattend in kaart te brengen is ongetwijfeld ook nog eens getemperd doordat Harting dit zelf al tamelijk breedvoerig heeft gedaan, in zijn autobiografie ${ }^{4}$. Hoe dan ook, in vergelijking

1 Pieter Harting werd op 27 februari 1812 in Rotterdam geboren als oudste zoon van een tabaksmakelaar. In 1828 begon hij de studie medicijnen te Utrecht en volgde hier onder meer de lessen van G. J. Mulder in de chemie, G. Moll in de fysica en J. L. C. Schroeder van der Kolk in de fysiologie. In 1835 promoveerde hij tot medicinae doctor, in 1837 tot doctor in de obstetrie. Een korte episode als arts in Oudewater volgde. In zijn vrije tijd deed Harting microscopische waarnemingen en chemische experimenten, en met name met zijn microscopische publikaties wist hij de aandacht op zich te vestigen. Dit leidde in 1841 tot een benoeming tot hoogleraar kruid-, schei- en artsenijmengkunde aan het Atheneum in Franeker. Na de opheffing van het Atheneum in 1843 werd Harting als buitengewoon hoogleraar aan de Utrechtse wis- en natuurkundige faculteit toegevoegd. Het ordinariaat volgde in 1846. In Utrecht doceerde Harting farmacologie, plantenfysiologie, vergelijkende anatomie en zoölogie. Vanaf 1858 concentreerde hij zich op de zoölogie. Harting ging in 1882 met emeritaat en overleed in 1885. Zie voor meer biografische bijzonderheden P. Harting, Mijne herinneringen. Autobiografie (Amsterdam, 1961); A. A. W. Hubrecht, 'Pieter Harting herdacht'. Jaarboek van de Koninklijke akademie van wetenschappen (1888) 1-35; C. H. D. Buys Ballot, 'Levensbericht van Pieter Harting', Levensberichten van de Maatschappij der Nederlandsche letterkunde te Leiden ( 1886-1887) 149-175; H. F. Jonkman, 'Pieter Harting', Mannen van beteekenis in onze dagen (Haarlem, 1886) 319-366.

2 K. van Berkel, In het voetspoor van Stevin. Geschiedenis van de natuurwetenschap inNederlandl5801940 (Amsterdam, 1985) 124-126.

3 Zie bijvoorbeeld J. C. Deiman, Microscope opties 1750-1850 (Londen, 1992) passim.

4 Harting, Mijne herinneringen. 
met zijn Utrechtse collega's, en ondanks de erkenning van zijn rol als bevorderaar van de natuurwetenschappen, is er door wetenschapshistorici weinig over Harting gepubliceerd ${ }^{5}$.

Historici daarentegen, met name politiek- en cultuurhistorici, hebben naar verhouding veel belangstelling voor Harting aan de dag gelegd. Hen was het dan onder meer te doen om Hartings bemoeienissen met de leerplicht en het schöolverbond ${ }^{6}$, zijn aandeel in de Nisero-affaire ${ }^{7}$, en vooral zijn prominente rol in de Transvaalbeweging ${ }^{8}$. Van Berkel heeft onlangs Hartings wetenschapshistorische interesse vanuit het perspectief van het negentiende-eeuwse cultureel-nationalisme belicht ${ }^{9}$. Te Velde, naar wiens belangrijke studie over liberalisme en nationalisme hier meermaals zal worden verwezen, zet Harting neer als een typische representant van het conservatiefliberalisme ${ }^{10}$.

Grosso modo valt de bestaande literatuur zo in twee categorieën uiteen. Wetenschapshistorici wijzen op Hartings rol als voorvechter van de natuurwetenschappen of concentreren zich op een aspect van zijn wetenschappelijk werk. Historici richten zich op Harting als publieke figuur. Enigszins hors catégorie is Hartings rol bij de verspreiding van het darwinisme in Nederland, waarover door historici, en niet door wetenschapshistorici, het een en ander is geschreven 11. Maar het darwinisme is door zijn politieke, sociale en religieuze implicaties dan ook een onderwerp dat welhaast traditioneel op de agenda van historici voorkomt. Een ander tussengebied is dat van de geschiedenis van het hoger onderwijs. In dit verband is recent door Wachelder aan

5 Zie P. J. Vinken, ' Pieter Harting en de afstamming van de mens ', Proceedings Koninklijke Nederlandse akademie van wetenschappen, Series C, Biological and medical sciences, LXVI (1963) 383-389, en het (slechts voor een deel aan Harting gewijde) artikel van R. P. W. Visser, 'De ontwikkeling van de universitaire biologische laboratoria', in: R. P. W. Visser, C. Hakfoort, ed., Werkplaatsen van wetenschap en techniek. Industriële en academische laboratoria in Nederland 1860-1940 (Amsterdam, 1986) 113123, m. n. 114-118. (Themanummer Tijdschrift voor de geschiedenis van de geneeskunde, natuurwetenschappen, wiskunde en techniek (Gewina, IX ( 1986) nr. iv)).

6 Zie bijvoorbeeld A. Winkler Prins, De quaestie van de leerplicht toegelicht aan de geschiedenis van het Schöolverbond (Culemborg, 1895); Th. W. M. Veld, Volksonderwijs en leerplicht. Een historisch sociologisch onderzoek naar het ontstaan van de Nederlandse leerplicht 1860-1900 (Leiden, 1987).

7 W. Ph. Coolhaas, 'De Nisero-kwestie. Professor Harting en Gladstone', Bijdragen en mededelingen van het historisch genootschap (1964) 271-325.

8 G. J. Schutte, Nederland en de Afrikaners. Adhesie en aversie. Over stamverwantschap, Boerenvrienden, Hollanderhaat, calvinisme en apartheid (Franeker, 1986) m. n. hoofdstuk 1; Ch. A. J. van Koppen, Geuzenvande negentiende eeu. A. Kuyper enZuid-Afrika (Maarssen, 1992)m.n. hoofdstuk 4; H. te Velde, Gemeenschapszin en plichtsbesef. Liberalisme en nationalisme in Nederland, 1870-1918 ('s-Gravenhage, 1992) m. n. hoofdstuk 3.

9 K. van Berkel, 'De beoefening van de wetenschapsgeschiedenis in Nederland in de tweede helft van de negentiende eeuw', Gewina, XVIII (1995) 181-191.

10 Te Velde, Gemeenschapszin en plichtsbesef, 66-74.

11 J. G. Hegeman, 'Darwin en onze voorouders. Nederlandse reacties op de evolutieleer 1860-1875. Een terreinverkenning', Bijdragen en mededelingen betreffende de geschiedenis der Nederlanden, LXXXV (1970) 261-314. Liesbeth Coffeng besprak recent Hartings behandeling van het darwinisme in het populair-wetenschappelijke Album der natuur: 'Het Album der natuur. Popularisering van de natuurwetenschap in een tijdschrift uit de eerste [sic] helft van de negentiende eeuw', Groniek, XXVII (1994) 52 66. 
Hartings opvattingen gerefereerd ${ }^{12}$. Maar al worden op deze grensvlakken de onderzoeker en de publieke figuur iets nader tot elkaar gebracht, de scheiding blijft toch bestaan. Pogingen om de 'twee Hartings' te integreren ontbreken.

In dit artikel zal ik een poging doen die integratie tot stand te brengen. Mijn uitgangspunt is dat Hartings opvattingen over maatschappelijke en wetenschappelijke kwesties een eenheid vormen. Hiermee bedoel ik niet te zeggen dat zijn wetenschappelijke stellingnames te deduceren zijn uit zijn politieke of sociale overtuiging, of omgekeerd, dat zijn ideeën als onderzoeker op een of andere manier zijn maatschappelijke opvattingen determineerden. Waar het mij om gaat is te laten zien dat er een samenhang en wisselwerking te onderkennen is in de manier waarop Hartings gedachten op zowel wetenschappelijk als maatschappelijk terrein gestalte kregen. Anders gezegd, Harting stond weliswaar aan het begin van het professionaliseringproces dat de natuurwetenschappen in de negentiende eeuw zouden doormaken, maar van een strikte scheiding tussen het wetenschappelijke en het maatschappelijke was bij hem nog geen sprake.

Enerzijds kan een dergelijke benadering het wetenschapshistorische belang van een erkend invloedrijk, maar weinig spectaculair onderzoeker als Harting beter uit de verf doen komen. Anderzijds hoop ik duidelijk te maken dat Hartings wetenschappelijke achtergrond van dusdanige betekenis was voor zijn maatschappelijke activiteiten, dat de historicus deze dimensie bij de interpretatie van Hartings publieke optreden niet kan negeren.

\section{De taak van de universiteit}

Hartings wetenschappelijke activiteiten in Franeker en Utrecht waren zeer divers. Er is een geleidelijke verschuiving in zijn interesse te zien van chemische en microscopische naar zoölogische onderwerpen, maar hij deed ook onderzoek op het terrein van de fysiologie, de botanie, de antropologie en de geologie. Deze breedte handhaafde Harting welbewust, en we kunnen hieruit opmaken dat zijn visie op wetenschappelijk onderzoek niet zonder meer aansloot bij het 'Duitse model', dat rond het midden van de negentiende eeuw een vast referentiepunt werd in discussies over het universitaire bestel in Nederland.

De zal hier niet ingaan op de achtergronden van dat Duitse model. Hierover is de laatste jaren een uitgebreide literatuur verschenen die het idee van de Humboldtiaanse universiteit diepgaand heeft geproblematiseerd en wat de natuurwetenschappen betreft heeft aangetoond dat het te simplistisch is Wilhelm von Humboldts ideologie van Forschung und Lehre te zien als het enige fundament waarop het indrukwekkende gebouw van de Duitse natuurwetenschappen werd opgetrokken ${ }^{13}$. Waar het Duitse

12 J. C. M. Wachelder, Universiteit tussen vorming en opleiding. De modernisering van de Nederlandse universiteiten in de negentiende eeuw (Hilversum, 1992) hoofdstuk 3 en 5.

13 Zie bijvoorbeeld Ch. E. McClelland, State society and university in Germany, I700-1914 (Cambridge, 1980); K. M. Olesko, ed., Science in Germany. The intersection of institutional and intellectual issues, themanummer Osiris, second series, V ( 1989); G. Schubring, ed., 'Einsamkeit und Freiheit' neu besichtigt. Universitätsreformen und Disziplinbildung in Preussen als Modell für Wissenschaftspolitik im Europa des 
model in de Nederlandse situatie naar verwijst - daar wil ik hier mee volstaan - is dat het bedrijven van zuivere wetenschap, specialismevorming, en het opleiden van studenten tot onderzoekers de idealen werden die door universitaire hoogleraren in de tweede helft van de negentiende eeuw werden nagestreefd. Daarvoor waren de universiteiten voornamelijk onderwijsinstituten die de studenten voorbereidden op toetreding tot de geleerde stand. De nadruk lag op persoonlijke vorming en geleerdheid, met daarin een spilfunctie voor de studie van de klassieke letteren. De natuurwetenschappen ontleenden hun bestaansrecht vooral aan hun plaats in de opleiding van geneeskundigen en hun algemene utilitaire strekking. Van een onderzoeksethos was begin negentiende eeuw aan de universiteiten nog geen sprake.

$\mathrm{Nu}$ lijdt het geen twijfel dat het onderzoeksethos later in de eeuw ook de Nederlandse universiteiten langzaam maar zeker is gaan domineren. Ook staat vast dat de opbloei van het natuurwetenschappelijk onderzoek rond het midden van de negentiende eeuw begon, met Utrecht als voortrekker. Maar dat zich in Utrecht de eerste tekenen van de overname van het Duitse model manifesteerden, is niet een conclusie die hier logisch uit voortvloeit. De zaak blijkt ingewikkelder. Voor Pieter Harting was de situatie in Duitsland op veel punten juist een voorbeeld van hoe het niet moest ${ }^{14}$.

In de brede oriëntatie van Hartings onderzoeksactiviteiten is hiervoor zoals gezegd een vingerwijzing te vinden. Tot het eind van zijn loopbaan bleef Harting een tegenstander van specialismevorming onder universitaire ordinarii. Een illustratie levert zijn reactie op de hoger-onderwijswet van 1876. In die wet-die inmiddels wel degelijk de invloed van Duitse voorbeelden weerspiegelde - werden binnen elke discipline nieuwe vakken beschreven waarin afzonderlijk onderwijs moest worden gegeven. Harting erkende de noodzaak tot taakverdeling, maar hij beschouwde dit toch vooral als een noodzakelijk kwaad. Hij bepleitte uiterste terughoudendheid en liet de Utrechtse curatoren desgevraagd weten dat het aantal hoogleraren wat hem betrof niet fors hoefde te worden uitgebreid ${ }^{15}$. Het was juist aan te bevelen dat professoren ook onderwijs gaven op terreinen die buiten hun eigen deskundigheid vielen. Dit noodzaakte hen zich breed te blijven ontwikkelen en kon voorkomen dat ze zich in een specialisme begroeven:

Het is zoo als Haeckel mij dezer dagen schreef: de meesten die zich zooiogen noemen houden zich op met 'Kleinigkeitskramerei'. Zij worden daardoor voor Akademische docenten, wier streven moet zijn een breeden wijsgeerigen grondslag te leggen, geheel ongeschikt ${ }^{16}$.

19. Jahrhunderts (Stuttgart, 1991 ); A. Tuchman, Science, medicine and the state in Germany. The case of Baden 1815-1876 (New York-Londen, 1993).

14 Ik concentreer me hier verder op Harting, maar merk nog wel op dat hij hierin zeker niet alleen stond. De opvattingen van Mulder en verschillende andere Utrechters kunnen evenmin adequaat worden gekarakteriseerd aan de hand van het Duitse model; Van Berkel (In het voetspoor van Stevin, 129) wijst ook al op tegenstand tegen het Duitse model.

15 Harting aan Utrechtse curatoren, 4 april. 1877, Faculteitsarchief wis- en natuurkunde, inv. nr. 197, 1867-1877. Zie verder Bedenkingen tegen eenige punten van het rapport der commissie belast met de herziening der geneeskundige staatsregelingen hier te lande (Utrecht, 1842) 13-14; Gedachten over het hooger onderwijs in ons vaderland (Tiel, 1858) 50; Voorheen en thans, 1828-1878. Herinneringen, opmerkingen en wenken door een oud-student (Utrecht, 1878) 48-56.

16 Harting aan G. Ph. F. Groshans, 11 juli 1868, Hartingarchief Utrechts Universiteitsmuseum (in het vervolg HUU). 
Om zijn brede blik werd Harting overigens ook door zijn studenten gewaardeerd. Een oudstudent roemde bijvoorbeeld 'de echt natuurwetenschappelijken geest, de universele, wijsgeerige richting van uw onderwijs en uwe studie ${ }^{17}$.

Hartings standpunt kwam voort uit zijn visie op de maatschappelijke rol en positie van de academicus. Zijn afkeer van specialisatie hield niet in dat hij het klassieke ideaal van universele geleerdheid wilde hooghouden. Het ging hem niet om het om zichzelfs wil nagestreefde ideaal van persoonlijke vorming en eruditie, maar om de opleiding van verlichte en nuttige staatsburgers ${ }^{18}$. Tegen het hyperindividualisme van het klassieke ideaal had hij zonder meer al zijn bezwaren. Hij zou geen liberaal zijn geweest als hij het individu niet als de 'centrale veer' in het 'raderwerk der maatschappij' had gezien, maar in 'volkomener maatschappijen' lagen het eigenbelang en het algemeen belang volgens Harting direct in eikaars verlengde ${ }^{19}$. Met zoveel woorden wilde hij de studie der klassieken vervangen door die van de natuurwetenschappen ${ }^{20}$. Academici vormden ook in zijn ogen een intellectuele voorhoede, maar die positie moest niet gebaseerd zijn op geleerdheid, noch op praktische bekwaamheid, maar op een verlichte, natuurwetenschappelijke maatschappijvisie.

Het hooger onderwijs heeft niet enkel de strekking van een zeker getal jongel ieden met de nodige kundigheden [vooreen beroep] toe te rusten. Ware dit het geval, dan zoude dit onderwijs beperkt kunnen worden tot die vakken, welke van onmiddellijke praktische toepassing zijn. [Hoger opgeleiden] behooren ook over het algemeen eenen hoogeren trap van beschaving en verlichting bereikt te hebben ... zij moeten wetenschappelijk ontwikkelde menschen zijn, in staat om te midden der maatschappij ... kennis en verlichting te verspreiden, en zoo elk in zijnen kring mede te werken om die maatschappij tot een hooger standpunt op te voeren ${ }^{21}$.

Met dit wetenschappelijke wereldbeeld als richtsnoer moesten academici zich dienstbaar maken aan de maatschappij. Want binnen de grenzen die aan het menselijk kenvermogen waren gesteld, hadden wetenschappers in Hartings optiek de wijsheid in pacht. Deze overtuiging stoelde op een positivistische wetenschapsopvatting die hij met veel tijdgenoten deelde. Kennis van de werkelijkheid, op welk terrein dan ook, berustte op empirisch onderzoek, op het onbevooroordeeld verzamelen van feiten. Via inductie regen die feiten zich tot hypothesen aaneen, en bij voldoende bevestiging hiervan door nieuwe waarnemingen konden de hypothesen tot theorieën en wetten worden verheven. Toekomstige waarnemingen konden altijd roet in het eten gooien, want wetenschap was geen afgerond systeem van weten, maar bleef altijd in ontwikkeling $^{22}$. Harting betwijfelde echter niet dat met het voortschrijdende natuuronderzoek

17 W. Koster aan Harting, 13 juni 1882, HUU.

18 Bedenkingen, 6-11.

19 'Iets over vergelijkende maatschappijkunde', Album der natuur (1863) 1-21, m. n. 2.

20 'Natuurkennis als opvoedingsmiddel. Een afscheidswoord', Album der natuur ( 1885) 393-398, m. n. 395; verder bijvoorbeeld Gedachten over het hooger onderwijs, 30-36.

21 Leerboek van de grondbeginselen der dierkunde in hare geheelen omvang (3 dln.; Tiel, 1862-1874) I(1862)ix-X.

22 Harting was in dit opzicht een duidelijke exponent van de 'historische wending' die zich vanaf 1840 in het denken over wetenschap voltrok. Zie hierover J. C. M. Wachelder, 'Wetenschappelijke vorming - 
de zekerheid over de juistheid van theorieën en de geldigheid van natuurwetten gestaag groeide $^{23}$. Ook stond het voor hem vast dat alle natuurverschijnselen aan vaste, onveranderlijke wetten gehoorzaamden ${ }^{24}$.

In Utrecht vond Harting in Gerrit-Jan Mulder en de filosoof C. W. Opzoomer medestanders voor deze wetenschapsopvatting. Opzoomer was echter nog sterk utilitaristisch ingesteld, hetgeen bij Mulder, en zeker bij Harting, veel minder het geval was. Voor Opzoomer moest alle natuurwetenschappelijke kennis useful knowledge zijn $^{25}$. Harting beklemtoonde daarentegen dat het allereerst ging om 'het opsporen van waarheid en niets dan waarheid, omdat men haar alleen om haarzelve liefheeft ${ }^{26}$. Dit droeg bij tot de

veredeling van den mensch, door zijnen geest te verrijken met kennis. [Het] eigenlijk streven is den sluijer op te ligten, welke het hoe en het waarom der dingen voor den onkundigen beschouwer bedekt, en de onveranderlijke wetten te leeren kennen, volgens welke de oneindige Schepper het groote heelal bestuurt ${ }^{27}$.

Kennis was dus een nastrevenswaardig doel op zichzelf, want geestelijke 'veredeling' was een voorwaarde voor maatschappelijke vooruitgang. Daarnaast leerde de geschiedenis van de natuurwetenschappen dat op kortere of langere termijn kennis en inzicht vanzelf tot praktisch bruikbare toepassingen leidden en zo ook in materiële zin tot de vooruitgang bijdroegen: 'de ware wetenschap, die zich niet verliest in ijdele bespiegelingen, maar de ervaring als leidsvrouwe heeft, [is] ook de beste grondslag voor alle praktische kennis' ${ }^{28}$.

Nam Harting dus afstand van een uitsluitend praktisch gemotiveerde wetenschapsbeoefening, hij vond wel dat 'nuttige kennis' het primaat moest hebben in het vakinhoudelijke deel van de universitaire opleiding. Want al was dat niet het enige oogmerk van de studie, de staat mocht met recht verlangen dat er ook in praktische zin nuttige staatsburgers werden opgeleid ${ }^{29}$. Ook stelde Harting zichzelf tot taak zijn wetenschappelijke kennis waar mogelijk dienstbaar te maken aan de maatschappij. Hieraan gaf hij onder meer gestalte door zitting te nemen in wetenschappelijke com-

een omstreden kwestie', in: L. C. Palm, G. Vanpaemel, F. H. van Lunteren, ed., De toga om de wetenschap. Ontwikkelingen in het hoger onderwijs in de geneeskunde, natuurwetenschappen en techniek in België en Nederland (1850-1940) (Rotterdam, 1993) 9-26, m.n. 13-18 (Themanummer Gewina, XVI (1993) nr. iii). Harting zelf zag dit ook zo: 'de historische school, die altijd rekening houdt met de ervaring van eeuwen en met bestaande toestanden [zal] in waardeering rijzen' (Wetenschap en geloof; een ernstig woord gesproken tot zijne leerlingen op 25 en 26 september 1876 (Utrecht, 1876) 57).

23 Harting zette zijn wetenschapsopvatting onder meer uiteen in Hoe men tot wetenschap komt, een blik in haar verleden, heden en toekomst (Utrecht, 1882) en in Wetenschap en geloof, 10-15.

24 Dr. Dioscorides [-Harting], Zijn er vaste natuurwetten? Een geschrift voor allen die beschaving op prijs stellen (Utrecht, 1885).

25 Zie voor Opzoomers wetenschapsopvatting C. W. Opzoomer, Het wezen der kennis, W. van Dooren, ed. (Baam, 1990).

26 Gedachten, 10; 'Johannes Florentinus Martinet', Album der natuur (1883) 1-23, m. n. 20.

27 'De hagel', Album der natuur (1853) 57.

28 Gedachten, 10; 'De ontdekking der bacteriën', Album der natuur (1884) 131-138, m. n. 138.

29 Gedachten, 10. 
missies die de regering van advies dienden inzake zulke kwesties als de paalwormbestrijding, de drinkwatervoorziening, de bodemdaling en de viskwekerij.

Hartings overtuiging dat het primaat bij zuivere kennisverwerving moest liggen spoort met het Duitse model, maar in de rol die hij aan het universitaire onderzoek toekende wijkt hij er toch weer duidelijk van af. De raison d'être van de universiteiten lag volgens Harting in 'het geven en ontvangen van onderwijs ${ }^{30}$. Onderzoek kwam pas op de tweede plaats. Toen in de jaren veertig werd voorgesteld de geneeskundige opleidingen aan één universiteit te concentreren, om zo een betaalbare en krachtige onderzoeksinstelling te verkrijgen, verzette Harting zich heftig. Een goed geoutilleerd onderzoeksinstituut zou ongetwijfeld de wetenschappelijke roem van de natie vergroten, maar voor de universiteiten lag hier niet de prioriteit. Universiteiten waren er voor het onderwijs, en concentratie van de opleiding zou ten koste gaan van het onmisbare intensieve contact tussen studenten en hoogleraren. De bescheiden onderzoeksfaciliteiten waarover hoogleraren in de bestaande situatie beschikten, waren voldoende om goed onderwijs te kunnen geven. Voor de studenten had het bovendien een grote vormende waarde dat ze zich met beperkte middelen moesten zien te redden ${ }^{31}$.

Dezelfde achtergrond hadden de pleidooien van Harting, Mulderen anderen voorde inrichting van universitaire laboratoria. In de eerste plaats waren die bedoeld voor de studenten, om praktische oefeningen te kunnen doen. De motivering was een pedagogische: zelf zien en zelf doen is veel effectiever dan demonstratie-onderwijs ${ }^{32}$. Het was uitdrukkelijk niet Hartings bedoeling de studenten tot gespecialiseerde onderzoekers op te leiden. Hij was er op tegen dat studenten onderzoek deden en beschuldigde studenten die daar op uit waren zelfs van misplaatste eerzucht ${ }^{33}$. Onderzoek en specialisatie waren zaken voor na de doctoraalstudie, wanneer men een werkkring had gevonden of wilde promoveren. De ambitie van de onderzoeksspecialist die in een bepaald deelgebied naam probeerde te maken, stond haaks op de veel bredere roldefinitie van Hartings ideale academicus. Vooral in de buurlanden, meende hij, bestond de neiging 'aan het lieve Ik de eerste, maar aan de wetenschap hoogstens de tweede

\footnotetext{
30 Bedenkingen, 7.

31 Ibidem, 7-16; Gedachten, 44-45, 52-53; Voorheen en thans, 48-56. In deze laatste publikatie, geschreven na de invoering van de hoger-onderwijswet, kreeg bij Harting het onderzoeksaspect meer nadruk; hij sprak nu van onderwijs en onderzoek als het tweeledige doel van de universiteit (ibidem, 56). Hij bleef echter tegen specialisatie door ordinarii gekant. Voor de specialismen kon men beter extraordinarii aanstellen (ibidem, 56-57). Aan de benoeming van privaatdocenten voor de specialismen, zoals dat in Duitsland gebeurde, kleefden in zijn ogen meer na- dan voordelen (Gedachten, 61-65).

32 'Ik ben namelijk altijd van oordeel geweest dat in natuurwetenschappen het onderwijs niet enkel theoretisch, maar ook praktisch moet zijn, en zoo heb ik ook steeds de gelegenheid voor zulke praktische oefeningen opengesteld', conceptbrief aan W. J. van Hoytema, 21 juni 1864, HUU; zie ook Over de belangrijkheid van mikroskopische onderzoekingen voor de geneeskunde (Utrecht, 1844). Over de opkomst van (universitaire) laboratoria: Visser, Hakfoort, Werkplaatsen.

33 Hartings standpunt, dat hij tot zijn emeritaat trouw bleef, wordt fraai geïllustreerd door een correspondentie met de Utrechtse fysioloog Th. W. Engelmann uit oktober 1878 (HUU). Harting wees hierin de onderzoeksaspiraties van een student van Engelmann af. Engelmann wierp tegen dat hij het stimuleren van zelfstandig onderzoek door studenten als zijn taak beschouwde en voor deze visie steun vond in de hogeronderwijswet. Zie ook Gedachten, 50.
} 
plaats' te geven ${ }^{34}$. Voor de nieuwe generatie Duitse specialisten kon hij dan ook weinig waardering opbrengen: 'Zij blijven opperlieden maar worden nooit architekten' ${ }^{135}$.

Een tweede functie van de laboratoria was dat ze de hoogleraren onderzoeksfaciliteiten verschaften en aldus de 'priesters van de wetenschap' in staat stelden tot de 'tempel der kennis' bij te dragen ${ }^{36}$. Maar ook hier legde Harting een verband met het onderwijs, dat door onderzoek van 'nieuwe gedachten' werd voorzien en een 'opwekkend' karakter kreeg ${ }^{37}$. De situatie in de late negentiende eeuw, waarbij de prioriteit in feite werd omgedraaid en de laboratoria als wetenschappelijke werkplaatsen voor docenten en gevorderde studenten gingen fungeren, zou door Harting volstrekt zijn afgekeurd ${ }^{38}$.

\section{De plichten van de natuuronderzoeker}

Hartings positivistische wetenschapsopvatting was, zoals bij Opzoomer, nauw verbonden met een modernistisch standpunt inzake het geloof. Althans impliciet, want zijn vanzelfsprekende protestantisme daargelaten weigerde Harting zich als verlicht wetenschapper met een bepaalde theologische richting te vereenzelvigen: 'ik ben geen aanhanger van eenige theologie ter wereld ${ }^{39}$. Keer op keer stelde hij in zijn geschriften dat de tijd voorbij was dat een bepaalde kerkleer de richtlijnen kon verschaffen voor wat men moest doen en laten of moest geloven en afwijzen. De traditionele rol van de religie was in de verlichte negentiende eeuw overgenomen door de wetenschap. ('Wie bezit, gelijk Gij, zoovéél en zoo veelzijdige wetenschap, en wie heeft er zoo den tact van, om de wetenschap zoo tot religie te maken', schreef de Haarlemse uitgever A. C. Kruseman hem $^{40}$.)

De wetenschap, aldus Harting, liet zien dat de natuur aan onwrikbare natuurwetten gehoorzaamt en zij had daarmee het geloof in wonderen definitief van elke basis beroofd. Ook wie, zoals hijzelf, in de natuur een openbaring Gods $\mathrm{zag}^{41}$, verkreeg alleen kennis over de wereld door rationele, onbevooroordeelde studie van de verschijnselen, en niet uit de bijbel. Geloof was voor Harting geen produkt van verstandelijke overweging, maar van het menselijk 'gemoed', dat daaraan een kennelijk nooit versagende behoefte voelde. Hiermee werd geloof een zaak van de persoonlijke beleving van het individu en verloor het elke supra-individuele maatschappelijke strekking. Verdraagzaamheid ten aanzien van ieders persoonlijke geloofsbeleving diende

34 Het mikroskoop, II (3 dln.; Utrecht, 1848-1850) 25.

35 Gedachten, 52. Nog in 1883 was hij wat dit betreft niet van mening veranderd: 'Johannes Florentinus Martinet', 19.

36 Gedachten, 44

37 Voorheen en thans, 8.

38 Typerend voor deze periode is de uitspraak van de Groningse botanicus Moll (geciteerd door Wachelder, 'Wetenschappelijke vorming', 24): '[D]e eerste en voornaamste plicht van een hoogleraar is het verrichten van oorspronkelijk wetenschappelijk onderzoek en het naar zijn vermogen bevorderen daarvan bij anderen. Het onderwijs, hoe gewichtig ook, komt toch, naar mijne opvatting, eerst in de tweede plaats in aanmerking'.

39 'Natuurwetenschap en theologie', overdruk uit Utrechtsch provinciaal en stedelijk dagblad ( 1885$) 4$.

40 A. C. Kruseman aan Harting, 14 oktober 1881, HUU.

41 'Eene terechtwijzing', Album der natuur (1871) 282-287, m. n. 283. 
vanzelfsprekend te zijn, aldus Harting. Tegenover rooms-katholieken kostte hem dit overigens moeite, gaf hij toe, vooral omdat zij zich hun geloofswaarheden door een autoriteit lieten opleggen die de moderne wetenschappelijke inzichten negeerde ${ }^{42}$. Een ander punt van zorg was dat, nu de breidel van de traditionele kerkleer was verdwenen, socialisme en communisme op de loer lagen, maar het antidotum was hier, zoals altijd: 'leert het volk denken' ${ }^{43}$.

Niet het geloof maar de wetenschap diende het richtsnoer te zijn voor de oordeelsvorming van de verlichte burger. Wetenschap rustte op feiten, zij formuleerde de onwrikbare wetten van de natuur, en kon daarom in maatschappelijke aangelegenheden als basis voor consensus dienen. Met dit laatste gegeven valt niet moeilijk in te zien hoe Hartings wetenschapsbeeld en zijn conservatief-liberale maatschappijopvatting op elkaar aansloten. Het idee dat alle mensen gelijk zouden zijn was 'dwaasheid', aldus Harting, en hetzelfde gold voor noties als volkssoevereiniteit en algemeen stemrecht ${ }^{44}$. Een ieder had de plicht het algemeen belang boven het particuliere belang te stellen. Het fundament waarop de maatschappelijke orde rustte, was nationaal gevoel en een eendrachtige opstelling in zaken van algemeen belang. De meningsvorming over het algemeen belang was echter niet een zaak van het volk als geheel, maar van een ontwikkelde en oordeelsbevoegde voorhoede, die geacht werd met de stem der natie te kunnen spreken en op wie het volk moest bouwen en vertrouwen. Of, in termen van het organistische maatschappijbeeld dat aan het conservatief-liberalisme ten grondslag lag, het volk vormde het lichaam van de natie, de elite het brein ${ }^{45}$. En dit brein kon in beproefde wetenschappelijke kennis volgens Harting een onbetwistbare consensusbasis vinden.

Natuuronderzoekers hadden voor Harting dan ook hun hoofdverantwoordelijkheid als leden van de maatschappelijke elite. Zij waren 'mannen, die door hunne kunde, graad van ontwikkeling, ja ook door zedelijk zelfbewustzijn van hetgeen plicht van hen vordert, hoog boven de meerderheid der menschen... staan ${ }^{\prime 46}$. Evenals Opzoomer beklemtoonde hij dat niet alleen het maatschappelijk optreden van natuurwetenschappers, maar ook van juristen, theologen, letterkundigen en politici in overeenstemming moest zijn met het verlichte, natuurwetenschappelijke wereldbeeld. In karakteristiek positivistische trant stelde hij:

bij zijn streven om de wetten te leeren kennen, die de menschelijke maatschappij beheerschen

42 Ibidem. Vgl. Te Velde, Gemeenschapsan en plichtsbesef, 36-38.

43 Wetenschap en geloof, een ernstig woord gesproken tot zijne leerlingen op 25 en 26 september $1 S 76$ (Utrecht, 1876)48-50.

44 Ibidem, 55-56. Hartings zeer kortstondige politieke carrière illustreert dit. Na de totstandkoming van de grondwet in $1848 \mathrm{nam}$ hij het secretariaat op zich van een van de nieuwe kiesverenigingen. Toen bleek dat 'politieke intriganten' de 'tot de mindere burgerij behoorende kiezers' opruiden om bepaalde, hem onwelgevallige kandidaten te kiezen, trok hij zich schielijk uit het bestuur terug. Om vervolgens te besluiten dat dit zijn laatste optreden op het kennelijk door ordinaire belangentegenstellingen gekenmerkte politieke toneel zou zijn (Mijne herinneringen, 62). Vgl. Te Velde, Gemeenschapszin en plichtsbesef, 4954,67 .

45 Ibidem, 22

46 'Philothérie of philanthropie', Album der natuur (1882) 131-142. 
[volge men] dezelfde inductieve methode, waarvan de natuurkundige zich bedient om de wetten der natuur te leren kennen ${ }^{\prime 47}$.

Daarom moesten aan studenten in alle richtingen de methoden en denkwijzen van de natuurwetenschappen worden bijgebracht, zonodig ten koste van de oude talen ${ }^{48}$. Want de tijd van de 'republiek der wetenschappen en letteren' kwam nooit weerom: 'De beschaving heeft zich allengs geheel nieuwe banen gebroken' ${ }^{49}$.

De maatschappelijke rol die Harting zichzelf als natuurwetenschapper toedacht, lag om te beginnen op het terrein van kwesties met een duidelijk wetenschappelijke component, zoals het al genoemde paalwormenprobleem. Een ander voorbeeld levert de opkomende antivivisectiebeweging. De vaderlijke vermaningen die hij de dierenbeschermers toevoegde ('Eilieve, geachte Mevrouw!') karakteriseren zijn conservatief-liberale instelling ten voeten uit. Het was niet dat hij geen sympathie kon opbrengen voor hun dierenliefde of hun bezwaren tegen vivisectie, legde hij uit, want zelf kon hij ook geen bloed zien. Waar hij tegen moest protesteren, was dat door sentimenten gedreven leken zich een oordeel aanmatigden over zaken die aan de rationeel denkende en ervaren mannen van de wetenschap overgelaten moesten worden. Men diende eenvoudig vertrouwen te hebben in hun plichtsbesef en verantwoordelijkheidsgevoel. En het was volkomen misplaatst zich tot de regering te wenden om de natuuronderzoekers beperkingen op te laten leggen. Waar de grenzen lagen, was nu juist een vraag die alleen de man van de wetenschap op een verantwoorde manier kon beantwoorden ${ }^{50}$.

Hartings inspanningen als popularisator van de natuurwetenschappen en volksopvoeder laten zich in dit beeld inpassen. Zijn doel was het met name in orthodoxe kringen bestaande wantrouwen tegenover de natuurwetenschappen weg te nemen. Natuurkennis was onmisbaar voor elke beschaafde burger, of hij nu landman was, ambachtsman, fabrikant of koopman. Onderwijs in de natuurwetenschappen moest onderdeel van het volksonderwijs worden. In het mede door hem geredigeerde Album der natuur lanceerde Harting de leus 'Natuurkennis als opvoedingsmiddel' en onder die vlag publiceerde hij ettelijke honderden grotere en kleinere stukken in het blad ${ }^{51}$.

De vrees van gelovigen dat het natuurwetenschappelijk denken tot atheïsme en materialisme leidde, miste volgens Harting elke grond. Om wetenschappelijke waarheden kon men niet heen, en wie daarin strijdigheden meende te bespeuren met zijn religieuze overtuiging had een verkeerde opvatting van het geloof. Het geloof in God was een gemoedszaak en als zodanig niet aan te tasten door de inzichten die langs de weg van rede en ervaring werden bereikt. Waar zich strijdigheden met theologische dogma's aandienden, moesten die dogma's eenvoudig als door de wetenschap achterhaald wor-

47 Wetenschap en geloof, 50; Gedachten, 19; 'Natuurkennis als opvoedingsmiddel' (1885) 395.

48 Gedachten, 27-36.

49 'Natuurkennis als opvoedingsmiddel' (1885) 395.

50 'Vivisectiên', Album der natuur (1874) 65-70; 'Eene psychologische studie naar aanleiding van een hangend vraagstuk', ibidem (1874) 161-184; 'Philothérie of philanthropie', 131-142.

51 'Natuurkennis als opvoedingsmiddel', Album der natuur (1855) 363-373; 'Natuurkennis als opvoedingsmiddel' (1885). Vgl. Coffeng, 'Het Album der natuur'. 
den beschouwd. De verlichte burger kon zich hier naar Hartings overtuiging moeiteloos bij neerleggen zonder zich in de essentie van zijn Godsgeloof aangetast te voelen ${ }^{52}$. Zoveel was zeker 'dat voortaan geen metaphysisch stelsel meer denkbaar is, waarvoor niet de natuurkundige wetenschappen den breeden, stevigen grondslag hebben geleverd ${ }^{53}$. Ondertussen bracht het boek van de natuur de rechtgeaarde gelovige evenzeer tot God als de bijbel: 'wie hem wil leeren kennen... mag geene dier beide openbaringen veronachtzamen' ${ }^{54}$.

Maar ook in niet-wetenschappelijke aangelegenheden liet Harting zijn stem horen en wees hij voortdurend op de spilfunctie van de natuurwetenschappen. Zijn stellingname in geloofszaken liet dit al zien. In hetzelfde perspectief kunnen we zijn bemoeienissen met allerlei politieke, sociale en culturele onderwerpen plaatsen. Voor Halting ging het hierbij ten minste voor een deel ook om wetenschappelijke kwesties; beter gezegd, Harting maakte geen scherp onderscheid tussen het wetenschappelijke, het politieke en het sociale. Aan alles legde hij zijn wetenschappelijke wereldbeschouwing ten grondslag, en in alles beschouwde hij zich als natuuronderzoeker tot oordelen bevoegd, en ook tot oordelen verplicht.

Een eerste voorbeeld levert de opkomende verzuiling, die door Harting en zijn geestverwanten als een regelrechte bedreiging van de eendracht en de stabiliteit van de natie werd ervaren. Met name de wetenschapsvijandige koers en het ultramontanisme van een grote groep zich emanciperende katholieken beschouwde hij als een anachronisme, een stap achteruit in de maatschappelijke ontwikkeling ${ }^{55}$. Zijn aanvankelijk wat mildere oordeel over Kuyper en de zijnen werd afwijzender naarmate hij Kuyper meer als een tweedrachtzaaier begon te beschouwen, een 'drijver' die de hogere klassen verdacht maakte bij de lagere: 'Zoo zal de revolutie eenmaal de noodzakelijke vrucht zijn van het onverstandig drijven der zoogenaamde antirevolutionairen ${ }^{56}$. Tegen bijzondere scholen had hij in eerste instantie weinig bezwaar. Het belangrijkste was dàt er werd opgevoed en onderwezen, en dat er gaandeweg een situatie zou ontstaan waarin de leerplicht op consensusbasis werd aanvaard. Tot dit doel richtte hij samen met zijn broer Dirk in 1869 het Schoolverbond op. Maar zijn preferentie van openbare scholen nam naar eigen zeggen sterk toe toen hem duidelijk werd dat bijzondere scholen als vehikel voor confessionele beginselen werden gebruikt die verlichting en beschaving_lees: het wetenschappelijke wereldbeeldjuist in de weg stonden ${ }^{57}$. Dit gaf hem een serie artikelen in de pen waarin hij de

\footnotetext{
52 'Natuurkennis als opvoedingsmiddel' ( 1855) 369. Zie ook iets over materialisme en materialisten, in verband met opvoeding en onderwijs', Album der natuur (1869) 129-150.

53 'lets over materialisme', 137.

54 Album der natuur (1852) 'Voorberigt'; De bouwkunst der dieren. Een boek voor allen die de natuur liefhebben (Groningen, 1862) 1.

55 Zijn verontrusting over de geloofstwist en de schoolstrijd maakte Harting onder meer kenbaar in een aantal artikelen in het Utrechtsen provinciaal en stedelijk dagblad: 'De natuurwetenschap tegenover de theologie' en 'Natuurwetenschap en theologie'. Samen met enkele andere werden deze artikelen gebundeld onder de titel Ernstige woorden tot zijne landgenooten (Amersfoort, 1885).

56 Ernstige woorden, 59.

57 'Eene terechtwijzing', 284.
} 
wetenschappelijke onhoudbaarheid van orthodoxe overtuigingen probeerde aan te tonen $^{58}$.

In de jaren zeventig en tachtig werden ook de internationale politieke ontwikkelingen door conservatief-liberalen in toenemende mate als een bedreiging van de integriteit van de natie ervaren. De Frans-Duitse oorlog van 1870-1871 deed de kwetsbaarheid van Nederland duidelijk uitkomen en tastte het zelfvertrouwen diep aan. Ook Harting reageerde geschokt op de oorlogsverklaring. In een opwelling, even naïef als typerend, schreef hij een brief - van intellectueel tot intellectueel — aan Victor Hugo, met de oproep om het 'arme misleide fransche volk' tot rede te brengen en tot vredesluiting te bewegen ${ }^{59}$. De 'vreeselijke gebeurtenissen der laatste weken' vormden ook het thema van zijn academische openingsles van dat jaar ${ }^{60}$. Politiek, geloof, en wetenschap gingen in deze, onder de titel De strijd des levens gepubliceerde rede vloeiend in elkaar over. Harting haalde er zich (naar later bleek) de woede van katholieken mee op de hals door te stellen dat de Fransen de oorlog niet ingegaan zouden zijn als de katholieke geestelijkheid het volk niet 'opzettelijk dom' had gehouden en het niet in zijn 'geloof aan mirakelen' had gestijfd ${ }^{61}$. Was er een rationele afweging gemaakt, dan had Frankrijk geweten dat het niet kon winnen.

De kansloosheid van de Fransen stond voor Harting bij voorbaat vast. Eén van zijn vele interessen was de antropologie, en een belangrijke, zoniet de hoofdreden voor zijn belangstelling was dat het onderzoek van rasverschillen de mogelijkheid bood de zo fundamenteel geachte kwestie van de nationale identiteit wetenschappelijk te onderbouwen. Ras, cultuur en nationaliteit werden in dit soort studies doorgaans zonder veel omhaal vereenzelvigd. Anatomische verschillen werden als verklaring voor verschillen in beschavingsgraad opgevat, cultuurverschillen werden teruggevoerd op raskenmerken, enzovoort ${ }^{62}$. Hartings werk was geen uitzondering. Dat de Fransen wel het onderspit móesten delven, vloeide voort uit het gegeven dat het Germaanse type, 'dat onder alle rassen bestemd schijnt de voornaamste drager der beschaving te zijn' nu eenmaal in alles superieur was aan het Keltische ${ }^{63}$. De dolichocefale schedel en het krachtige fysiek van de Germanen gingen op natuurlijke wijze samen met een hoge verstandelijke ontwikkeling, een rationele instelling en een volwassen gedrag-even natuurlijk als bij de Keltische brachycefale schedel de negatieve variant van al deze eigenschappen hoorde. Nu erkende Harting dat noch het Franse, noch het Duitse volk het oorspronkelijke 'type' in 'zuivere' vorm vertoonde en dat er een voortschrijdende

\footnotetext{
58 Zie noot 55.

59 Mijne herinneringen, 104-105.

60 De strijd des levens (Utrecht, 1870) 5.

61 Ibidem, 20. Deze passage kwam Harting op een aanval van enkele jezuïeten te staan; zie H. te Braake, 'Natuurkunde en godsdienstige begrippen, of antwoord van prof. Harting op de vraag: 'Heeft de natuurkunde op de neutrale school eene materialistische strekking?", Studiën op godsdienstig, wetenschappelijk en letterkundig gebied, III (1871) 8 en de correspondentie met J. Amzt SJ in HUU. Harting reageerde op Te Braakes aanval met 'Eene terechtwijzing'.

62 Voorbeelden zijn in welhaast elke studie over negentiende-eeuwse rastheorieën te vinden. Ik noem slechts N. Stepan, The idea of race in science. Great Britain, 1800-1960 (Houndmills, BasingstokeLonden, 1982); G. W. Stocking, Victorian anthropology (New York, 1987).
}

63 De strijd des levens, 18. 
vermenging van de twee typen plaatsvond. Maar niettemin overheerste in Frankrijk toch het Keltische erfgoed, in Duitsland het Germaanse, en dus was de afloop van de oorlog voorspelbaar.

Belangrijk was natuurlijk de vraag bij welk type de Nederlander moesten worden ingedeeld. Hier was gelukkig geen reden tot zorg. Harting had de kwestie van de nationale raskenmerken al eerder onderzocht, namelijk met zijn bekende studie over het eiland $\mathrm{Urk}^{64}$. De eilandbewoners vertegenwoordigden volgens Harting door hun sedert eeuwen nauwelijks veranderde levenswijze en door de beslotenheid van hun gemeenschap - Urkers trouwden bijna altijd met Urkers - een in redelijk ongeschonden staat bewaard gebleven relict van de oerpopulatie van Nederland: 'On pouvait espérer d'y rencontrer la race aborigène passablement pure ${ }^{165}$. Nu kon Harting uit de drie sterk variërende Urker schedels die hij wist te bemachtigen weinig specifieke kenmerken destilleren. Maar behalve dat de Urkers hem als 'stevig gebouwde, welgemaakte menschen' voorkwamen en dat veel van de vrouwen 'aanspraak op schoonheid' konden maken, was er toch wel één conclusie te trekken waarover nauwelijks twijfel kon bestaan: de Urker schedels lieten zien dat de oerhollanders geen Kelten waren geweest ${ }^{66}$.

Evenals anatomische en antropologische kenmerken waren de 'volksaard' en het niveau van culturele ontwikkeling voor Harting intrinsieke kenmerken van de nationale identiteit. En zoals rasvermenging die identiteit kon bedreigen, zo kon ook een aantasting van de volksaard en de cultuur dat doen. Hartings bezorgdheid op dit vlak vormde vaak de aanleiding om tegen allerlei maatschappelijke ontwikkelingen in het geweer te komen. Een krachtige volksaard werd volgens Harting in stand gehouden door 'strijd ${ }^{67}$. Daarom waren de noordelijke rassen superieur aan de mediterrane en zeker de equatoriale: de laatsten hoefden zich nauwelijks in te spannen om in leven te blijven, de eersten waren door de veel ongunstiger klimaat- en voedselsituatie naar een hoger plan opgestuwd ${ }^{68}$.

In de jaren zestig voegde Harting zich bij het koor van conservatief-liberalen dat meende te moeten waarschuwen voor de verwekelijking, de 'ontzenuwing' van het volk $^{69}$. Hij hekelde met name de gemakzuchtige en materialistische instelling die hij bij de jeugd waarnam en die naar zijn idee voortkwam uit de relatieve voorspoed en de afwezigheid van oorlog in Nederland. In het lager en middelbaar onderwijs werd onvoldoende zorggedragen voor de ontwikkeling van het gemoed:

het ontbreekt het tegenwoordige jonge geslacht aan geestdrift; het is te koel, te nuchter, te

64 Het eiland Urk, zijn bodem, voortbrengselen en bewoners (Utrecht, 1853).

65 'Le plan médian de ia tête Néerlandaise masculine, déterminé d'après une méthode nouvelle'. Verhandelingen Koninklijke akademie van wetenschappen, XV (1874) 2.

66 Het eiland Urk, 59,68. Harting wist later nog een paar Urker schedels in zijn bezit te krijgen; zie B. Theunissen, 'Ik heb de schedels in mijnen koffer geborgen', NRC-Handelsblad 'Achterpagina', 1 mei 1995 .

67 De betekenis van dit woord onderging bij Harting in de jaren 1860 een verschuiving. Ik kom hier op terug.

68 'De plantengroei in de keerkringgewesten. Een tafereel', Album der natuur (1852) 20-21.

69 Vgl. Te Velde, Gemeenschapszin en plichtsbesef, 58,78, 155-156, 159, 188. 
positief, te realistisch geworden ... Een warm hart en een koel hoofd, - dat is het wat een mensch maakt ${ }^{70}$.

Men zou hier met een beschuldigende vinger naar het natuurwetenschappelijk onderwijs kunnen wijzen, vervolgde hij, maar dan kon het toch alleen maar gaan om de manier waarop dat onderwijs werd gegeven, en niet om de natuurwetenschappen zelf. Want de natuurstudie droeg juist bij aan de ontwikkeling van het gemoed, vanwege 'het vele schoone en voortreffelijke, dat zij den beschouwer aanbiedt, om de levendige, den mensch veredelende gewaarwordingen, waarvan zij de steeds rijkelijk vloeiende bron is ${ }^{171}$.

Hartings ongerustheid over de vermeende verwekelijking klinkt in de politieke (maar in zijn eigen ogen vooral humanitaire) acties die hij in zijn latere levensjaren ondernam duidelijk door. De voorbeeldfunctie die de nog steeds 'dappere' en 'edelmoedige' Zuidafrikaanse nazaten van de eens zo koene Hollanders konden vervullen, was een van de motieven voor zijn prominente aandeel in de Nederlandse acties voor de Transvaalse Boeren in de jaren tachtig ${ }^{72}$. In de Nederlandse steunbetuigingen aan de Boeren zag Harting een teken dat 'ook in onzen tijd, te midden van den niet te vermijden strijd des levens, - wat pessimisten en materialisten ook beweren mogen, - het goede macht heeft' en dat het Nederlandsche volk nog in staat was op 'zuiver moreelen' grond naar 'het ideale' te streven ${ }^{73}$.

Waar Nederland zijn identiteit en integriteit tegenover de grootmachten niet met militair machtsvertoon kon bekrachtigen, onderschreef Harting de breedgedragen opvatting dat het des te belangrijker was de nationale cultuur te versterken, om zo het zelfbewustzijn te schragen en respect naar buiten af te dwingen. Zijn bijdrage aan het cultureel-nationalisme bestond vooral uit het in herinnering roepen van het roemruchte verleden van de Nederlandse natuurwetenschappen ${ }^{74}$. Refererend aan de glorietijd van de Republiek schreef hij:

Een herwinning onzer politieke stelling is evenmin mogelijk als wenschelijk, maar wat wel mogelijk, wat niet alleen wenschelijk, maar ook onze plicht is, dat is ... mee te werken aan het groote werk der beschaving, ook door bevordering en ondersteuning van elke poging, die ten doel heeft den schat van kennis te vermeerderen, welke het gezamenlijk eigendom is niet van deze of gene natie, maar van het geheele menschdom. Wij zijn verplicht daarin ons aandeel bij te dragen en tevens is dit het beste en het waardigste middel om onze naburen achting in te boezemen en ons zelfstandig volksbestaan te doen eerbiedigen ${ }^{75}$.

Met name in de natuurwetenschappen konden de Nederlanders excelleren, want anders dan 'onze stamgenooten aan den overzijde van den Rhijn', waren zij 'nuchter',

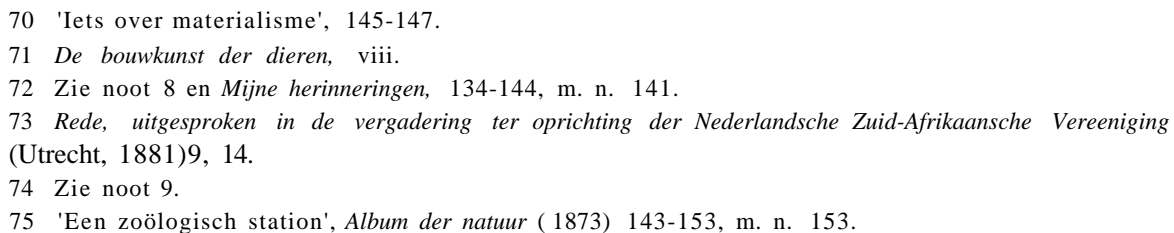


'positief' en 'bedachtzaam, ${ }^{176}$. Harting benadrukte verder dat de Nederlandse pioniers 'zuivere wetenschap' hadden voortgebracht en juist daaraan hun belang voor de beschaving ontleenden. Zijn helden waren

ontdekkers van nieuwe waarheden, door wie, zonder eenig bijoogmerk, zonder acht te slaan op het nut voor het stoffelijk welzijn des menschen, dat er wellicht te eenigen tijd uit zoude kunnen voortvloeien, uitsluitend de weetlust bevredigend, de zekere kennis aangaande het bestaande wordt uitgebreid ${ }^{77}$.

In de vele comité's en commissies die in deze tijd werden opgericht om de nagedachtenis van vaderlandse helden van de wetenschap te eren, speelde Harting veelal een centrale rol. De geschiedenis van de wetenschap onderstreepte in zijn ogen de cruciale rol van de natuurwetenschappen in de vooruitgang van de beschaving. Het geschiedenisonderwijs moest dan ook

ophouden louter eene geschiedenis van koningen en keizers, van veldslagen en andere groote gebeurtenissen te zijn, maar vooral eene geschiedenis der cultuur en van de ontwikkeling der denkbeelden worden ${ }^{78}$.

Zoals al doorklinkt in Hartings waarschuwen voor 'ontzenuwing', maakte het optimisme van de conservatief-liberalen vanaf de jaren zestig langzaam maar zeker plaats voor een steeds somberder visie op de toekomst van Nederland ${ }^{79}$. De toon van Hartings geschriften bleef weliswaar opwekkend, maar pessimisme en moedeloosheid gingen steeds meer overheersen in de brieven die hij met geestverwanten over allerlei maatschappelijke kwesties wisselde ${ }^{80}$. In de jaren voor zijn dood bereikte de mineurstemming een dieptepunt. Tekenend zijn passages als deze, uit een brief van P. F. Hubrecht aan Harting:

Wat mij in uwen brief bijzonder treft is de bij Uw vroeger onverstoorbaar optimisme thans zoo fel afstekende tint van groote somberheid, die zich blijkbaar over Uwe levensbeschouwing heeft uitgespreid, of liever nog die het wereldlandschap voor Uw oog somberder kleurt dan dusver ooit het geval was. Niet dat daartoe geen aanleiding zou bestaan; wie kan het ontkennen? ... nu begint ook [aan U] waarlijk — en niet zonder reden — de toestand van staat en maatschappij dermate op een hellend vlak geplaatst te schijnen, dat [U] met genoegen eraan denken kan het product dezer factoren niet meer te zullen beleven ${ }^{81}$ !

Opzoomer deelde in de malaise:

76 'Hallucinatie en verwante verschijnselen', Album der natuur (1873) 192.

77 Gedenkboek van het den 8sten september 1875 gevierde 200-jarig herinneringsfeest der ontdekking

van de mikroskopische wezens, door Antony van Leeuwenhoek ('s-Gravenhage-Rotterdam, 1876) 8.

78 'Natuurkennis als opvoedingsmiddel' (1885) 398. Zonder hem te noemen parafraseerde Harting hier de centrale these van Emil du Bois-Reymonds bekende rede 'Culturgeschichte und Naturwissenschaft' uit 1877.

79 Te Velde, Gemeenschapszin en plichtsbesef, 56-62.

80 Ibidem, 67-71.

81 Brief Hubrecht aan Harting, 27 november 1884, afschrift in HUU, map 'Leidse brieven'. 
Het zal U wel gaan als mij; overal, ook in ons vaderland, is er veel wat tot diepe somberheid moet stemmen, ons vooral, die met zoo groote opgewektheid ons eens lieten aanwerven in de gelederen van verlichting en beschaving. Wat zag het er toen alles veelbelovend uit! Wat hunkerde aan onze hoogescholen en in onze burgerij alles naar kennis, kennis van de natuur en de maatschappij.

Maar in de tegenwoordige tijd was alles weer 'kerk en openbaring ... bijbel en kruis [in de] zalen van wetenschap en van staatskunst'. En: 'Zullen we hier den vetten en vruchtbaren grond krijgen voor revolutie, voor socialisme en plundering en vernieling? En dat onder de opruiing der antirevolutionairen het meest ${ }^{182}$ !

In Hartings bemoeienis met Zuid-Afrika en, wat later, met de jodenvervolging in Rusland, is op de achtergrond zijn streven naar nationale eendracht steeds duidelijk te onderkennen:

Nederland is de klassieke bodem van verdraagzaamheid, waar Joden en Christenen sedert eeuwen vreedzaam naast elkander leven. Toonen wij aan de wereld, dat dit nog altijd zoo is,... dat in Nederland boven alle geloofsverschil zich een geest verheft, die al zijne inwoners tot een eendrachtig volk verbindt, namelijk: de geest der menschelijkheid ${ }^{83}$.

De ommekeer in Hartings perceptie van de toestand van de natie weerspiegelt zich ook in zijn wetenschappelijk werk, met name in zijn interpretatie van Darwins evolutietheorie.

\section{Evolutie en vooruitgang}

Eerst iets over Hartings onderzoek in het algemeen. Ondanks de brede onderwerpskeuze zijn er constanten aan te wijzen die duidelijk verband houden met het voorafgaande. Gegeven dat de wereldbeschouwing van de verlichte negentiende-eeuwer volgens Harting een wetenschappelijke grondslag moest hebben, valt te verwachten dat zijn aandacht vooral uitging naar wetenschappelijke onderwerpen waaraan in dit verband traditioneel een grote betekenis werd toegekend. Voor biologen waren dit vraagstukken als de oorsprong en de ontwikkeling van het leven, de doelmatigheid van levende wezens, het verschil tussen mens en dier en, zoals al besproken, de verschillen tussen de mensenrassen. Hartings werk blijkt met zulke fundamentele en voor hem ook maatschappelijk relevante kwesties steeds direct of indirect samen te hangen.

Een eerste voorbeeld levert het microscopisch onderzoek waarmee hij zijn wetenschappelijke carrière in de jaren veertig begon. Voor een belangrijk deel richtte hij zich hierbij op de eind jaren dertig door Schleiden en Schwann geformuleerde celtheorie ${ }^{84}$. Door de opstellers van de theorie werd de cellulaire opbouw van levende wezens gepresenteerd als een argument vooreen mechanistische visie op levende wezens, die

82 C. W. Opzoomer aan Harting, 4 oktober 1885, afschrift in HUU, map 'Leidse brieven'.

83 Comité ter ondersteuning der hulpbehoevende Israëlieten in Rusland, Oproep Utrechts comité jodenvervolging Rusland (Utrecht, 1882).

84 Voor wat hier volgt over de achtergronden van de introductie van de celtheorie, zie T. Lenoir, The strategy of life. Teleology and mechanics in nineteenth-century German biology (Dordrecht, 1982). 
in de plaats diende te komen voor de teleologische opvatting die op dat moment dominant was.

Het doelmatig functioneren van organismen en fenomenen als voortplanting, groei en regeneratie werden in de eerste helft van de negentiende eeuw veelal als verschijnselen gezien die niet uitputtend in wetenschappelijke termen verklaard konden worden. Vooral de oorsprong van de doelmatigheid van levende wezens en van de 'harmonie' van de levende natuur als geheel vielen buiten het verklaringsbereik van de natuuronderzoeker. Hier kon men slechts verwijzen naar God en diens scheppingsplan. Theodor Schwann betoogde echter in zijn Mikroskopische Untersuchungen uit 1839 dat op basis van zijn celtheorie wel degelijk een wetenschappelijke verklaring mogelijk was. Levende wezens waren opgebouwd uit zowel naar vorm als functie zelfstandige eenheden. Hun functioneren kon volledig uit de eigenschappen van de cellen worden verklaard, zoals ook de werking van een machine uit zijn onderdelen kon worden afgeleid. Er was dus geen reden om aan te nemen dat levende wezens meer waren dan de som van hun delen of dat er 'doeloorzaken' of vitalistische krachten werkzaam waren die de harmonie van het geheel bewerkstelligden.

Dit verschoof het probleem in eerste instantie natuurlijk alleen maar naar de cellen. Maar Schwann kwam met aanwijzingen dat het ontstaan van cellen veel overeenkomsten vertoonde met kristallisatieprocessen in de anorganische natuur. In concreto ging hij hierbij uit van de (naar later bleek foutieve) theorie dat nieuwe cellen tussen bestaande cellen in ontstonden als gevolg van het uitkristalliseren van allerlei stoffen in een tussencelvloeistof. Hier was volgens Schwann sprake van een wetmatig, fy sicochemisch proces waarbij slechts blinde natuurkrachten in het geding waren. De strekking was duidelijk: het ontstaan van 'leven' kon wellicht toch langs natuurwetenschappelijke weg worden verklaard; de aanname van specifieke levenskrachten was overbodig.

Het was deze mogelijkheid tot wetenschappelijke verklaring van het ontstaan van het leven die Hartings belangstelling wekte. Met behulp van zijn microscoop startte hij een onderzoek naar het uitkristalliseren van allerlei stoffen in een variëteit aan vloeistoffen. Waar het hem uiteraard om ging, was om te zien of er combinaties konden worden samengesteld waarbij de bezinksels overeenkomsten vertoonden met de organische structuren waaruit levende wezens waren opgebouwd. De resultaten leverden geen doorslaggevende bewijzen op, maar Harting interpreteerde ze toch als een aanwijzing dat levende structuren inderdaad langs zuiver fysico-chemische weg konden zijn ontstaan $^{85}$.

Evenmin als voor Schwann had dit gegeven voor Harting een atheïstische strekking. De natuur (zowel de levende als de niet-levende) bleef voor hem een harmonieus geheel. Het ontstaan van doelmatigheid kon wetenschappelijk worden verklaard, maar het feit dàt er doelmatige wezens ontstonden, dàt er harmonie was in de natuur en dat het juist déze harmonie was en niet een andere, kon alleen maar aan Gods voorzienig-

85 Hartings belangrijkste publikaties over het onderwerp verschenen in de jaren 1840. Een overzicht biedt Recherches de morphologie synthétique sur la production artificielle de quelques formations calcaires organiques (Verhandelingen der Koninklijke akademie van wetenschappen XIII; Amsterdam, 1872). 
heid worden toegeschreven. Daarom bleef voor Harting gelden: 'onderzoek de Schepping, en gij zult den Schepper zelve nader leeren kennen ... den Goddelijken bouwmeester [openbaart] zich van den aanvang af in zijne werken ${ }^{\prime 86}$. Wat zijn resultaten volgens hem aantoonden, was dat de natuuronderzoeker slechts met onwrikbare natuurwetten te maken had en in zijn natuurstudie geen rekening hoefde te houden met teleologische of vitalistische beginselen, noch met een voortdurend of zelfs maar zo nu en dan interveniërende God. Met andere woorden, in de celvorming vond hij een bevestiging voor zijn wetenschappelijke en modernistische wereldbeschouwing.

Hartings belangstelling voor de ontwikkeling van het aardse leven blijkt ook uit zijn werk op paleontologisch en zoölogisch gebied. De verschuiving van zijn interesse naar dit terrein in de jaren vijftig kwam waarschijnlijk rechtstreeks voort uit het toen alom bediscussieerde ontwikkelingsvraagstuk. Zoals menige tijdgenoot overwoog hij al voor het verschijnen van Darwins Origin of Species de mogelijkheid van transformatie. Hij plaatste zich in een wat selecter gezelschap door zijn ideeën hieromtrent ook al voor Darwin op papier te zetten, in zijn in 1857 gepubliceerde De voorwereldlijke scheppingen. Hierin beschreef hij de toentertijd circulerende ideeën over transformatie, waaronder die van Lamarck en Robert Chambers, als een 'vernuftige gissing'. Maar hij vermoedde toen nog dat 'noch de schrijver noch de lezers van dit boek' de wetenschappelijke onderbouwing van die gissing zouden meebeleven ${ }^{87}$. Er is overigens geen aanleiding Harting op te nemen in de rijen van 'voorlopers van Darwin', een exercitie waarmee een vroegere generatie wetenschapshistorici nogal gepreoccupeerd was. Als we van voorlopers van Darwin willen spreken, waren dat er vele, maar Darwin blijft hoe dan ook uniek vanwege het a-teleologische evolutiemechanisme dat hij introduceerde (de natuurlijke selectie) en de ongeëvenaarde empirische onderbouwing die hij zijn ideeën meegaf. Hartings gedachten over transformatie behelsden evenmin iets anders dan indertijd in brede kring levende veronderstellingen.

Na het verschijnen van de Origin trok vooral de kwestie van het verschil tussen mens en dier Hartings aandacht, een heet hangijzer in het evolutiedebat. Hij publiceerde er een groot aantal artikelen over, waarin hij steevast tot de conclusie kwam dat het verschil slechts gradueel was ${ }^{88}$. Uit allerlei gedragsuitingen meende hij te kunnen concluderen dat ook dieren tot op zekere hoogte in staat waren tot premeditatie en redeneren; ze konden liefhebben en haten, hadden schoonheidsgevoel en bezaten een zekere mate van zelfbewustzijn. Elk dier bezat 'behalve het instinct, ook hoogere vermogens ... waardoor het zich als een bezield wezen, dat is als een wezen, hetwelk zich van vele zijner handelingen volkomen bewust is, aan ons openbaart ${ }^{89}$. De mens onderscheidde zich door de mate waarin zijn verstandelijke vermogens hem onafhankelijk maakten van zijn dierlijke aandriften, waardoor hij vatbaar was voor beschaving

86 De voorwereldlijke scheppingen (Tiel, 1857) I, 35.

87 De voorwereldlijke scheppingen, I, 366-392, m. n. 392.

88 De meeste van deze artikelen verschenen in het Album der natuur. Typerende voorbeelden zijn 'Denken de dieren bij hetgeen zij doen', Album der natuur (1869) 73-76, en 'Bijdragen tot de dierlijke psychologie', Album der natuur (1872) 304-306. Andere voorbeelden zijn te vinden in De bouwkunst der dieren.

89 De bouwkunst der dieren, 10-11. 
en in staat werd gesteld de wereld om hem heen wetenschappelijk te benaderen ${ }^{90}$. Het verschil was groot, maar vanuit biologisch oogpunt niet fundamenteel. De strijd om het bestaan zoals die volgens de evolutietheorie in het planten- en dierenrijk voortdurend werd gestreden, was bijvoorbeeld ook in de menselijke samenleving bepaald niet verdwenen.

Dit brengt ons bij Hartings receptie van Darwins evolutietheorie. Harting staat te boek als een van de Nederlandse verdedigers van Darwin van het eerste uur, maar aan de achtergronden van zijn acceptatie van de theorie is geen aandacht besteed. Anders dan zijn vroege belangstelling voor de transformatiekwestie doet vermoeden, zijn er aanwijzingen dat die acceptatie bij Harting niet probleemloos verliep. Het voortdurend in elkaar overlopen van zijn wetenschappelijke ideeën en zijn wereld- en mensbeeld plaatste hem hier voor een dilemma. Dit dilemma ontstond door de spanning tussen Hartings idee van de 'harmonie van de schepping' en de darwiniaanse notie van de 'strijd om het bestaan'. De uitweg die hij uiteindelijk vond, berustte enerzijds op een in wezen 'on-darwiniaanse' interpretatie van de evolutietheorie, en anderzijds op een bijstelling van zijn visie op de menselijke conditie en de maatschappelijke ontwikkeling. Dit vergt enige toelichting.

In de jaren veertig en vijftig domineerde in Hartings werk de harmoniegedachte. Vooral in zijn populaire geschriften wees hij telkens weer op de 'heerlijke en doeltreffende orde in de gansche natuur' ${ }^{\prime 1}$. Al het geschapene had daarin een nuttige plaats en droeg zijn steentje bij aan de evenwichtige compositie van het geheel. De natuuronderzoeker kon dan ook niet anders dan steeds opnieuw onder de indruk raken van de 'grootheid en de almagt des Wetgevers' aan wiens voorzienigheid dit alles ontsproten was ${ }^{92}$.

$\mathrm{Nu}$ was het er Harting in zijn populaire artikelen allereerst om te doen natuurkennis te verspreiden, niet om langs fysico-theologische weg tot godsvrucht op te wekken. De verwijzingen naar harmonie waarmee zijn uiteenzettingen vaak eindigden, hadden vooral de bedoeling te laten zien dat natuuronderzoek niets afdeed aan het geloof maar er integendeel juist een ondersteuning aan gaf. Maar uitsluitend retorisch waren deze verwijzingen zeker niet. De harmoniegedachte sloot ook aan bij Hartings wereldbeeld, dat gekenmerkt werd door een optimistische mensvisie, vooruitgangsgeloof, nationale eendracht en beschaafde, op wederzijds respect gebaseerde internationale verhoudingen. Verwijzingen naar strijd komen in deze periode in zijn geschriften bijna niet voor. Zelfs in de uiteenzetting van evolutionaire denkbeelden die Harting al in 1857 gaf, ontbrak elke verwijzing naar strijd. Evolutionaire ontwikkeling was een vreedzaam proces, een zich langzaam ontvouwen van het Goddelijke plan ${ }^{93}$. In de zeldzame gevallen dat Harting van strijd sprak, had de term geen gewelddadige strekking maar verwees hij naar algemene liberale noties als 'geen vooruitgang zonder inspanning'. Het ontbreken van de noodzaak strijd te leveren was bijvoorbeeld de reden van de beschavingsachterstand van de equatoriale volkeren:

90 Ibidem, 12-14.

91 'Het sluimerende leven', Album der natuur (1854) 6.

92 Ibidem, 32.

93 De voorwereldlijke scheppingen, 366-392. 
De nood is de beste leermeesteres van den mensch. Vadzig en traag blijft hij daar, waar hij geene moeite behoeft aan te wenden om in zijne volstrekte behoeften te voorzien ... Maar daar, waar de natuur in strijd is met den mensch ... daar scherpt zich zijn geest en wet zich zijn verstand. Daar toont hij de heer der natuur te zijn; ginds is hij slechts haar kind ${ }^{94}$.

In de jaren zestig en zeventig werd Hartings toon wezenlijk anders. Enerzijds begon zijn optimisme in deze tijd af te kalven onderinvloed van de verzuiling, de schoolstrijd en de internationale politieke ontwikkelingen. Anderzijds drong zich de evolutionistische metaforiek van the struggle for life en the survival of the fittest aan hem op. Het heeft geen zin hier oorzaak en gevolg te willen onderscheiden. Tekenend is juist weer de verwevenheid van wetenschappelijke en maatschappelijke factoren in de verandering die Hartings denken in deze tijd onderging.

Evenzeer typeert het Halting dat hij in eerste instantie besloot Darwins theorie in zijn populaire werk niet te bespreken. De enige plaats waar hij met zoveel woorden zijn voorwaardelijke instemming met Darwin betuigde is het leerboek voor zijn studenten dat hij in 1862 publiceerde. Hierin noemde hij de evolutietheorie een 'zeer vruchtbare hypothese $^{195}$. Voor het overige hield hij de discussie binnenskamers. Toen bijvoorbeeld H. Hartogh Heys van Zouteveen (vanaf 1872 de radicale redacteur van het natuurwetenschappelijke tijdschrift $I s i s)^{96}$, een artikel over de evolutionaire ontwikkeling van de mens in het Album der natuur wilde publiceren, kreeg hij hiervoor van Harting geen toestemming ${ }^{97}$. Ondertussen mocht Hartings collega Jan van der Hoeven, Leids hoogleraar zoölogie en pertinent tegenstander van de evolutietheorie, in het Album wèl zijn bezwaren uiteenzetten ${ }^{98}$.

Hegeman vraagt zich af of Hartings terughoudendheid voortkwam uit reverentie voor Van der Hoeven, maar dit zal zeker niet de enige reden zijn geweest ${ }^{99}$. Hartings opstelling kan om te beginnen ook worden teruggevoerd op de vaderlijke rol die hij zich ten aanzien van het ongestudeerde volk aanmat. De evolutietheorie behoefde nog veel additionele bewijzen voor ze als wetenschappelijke waarheid kon worden gepresenteerd, en tot zolang was het niet verstandig onrust onder het volk te zaaien. Het

94 'De plantengroei in de keerkringgewesten', 21.

95 Leerboek der dierkunde, 312. Een bedekte verwijzing is ook te vinden in een lezing die hij in 1863 voor het Utrechtse natuurkundig gezelschap hield, waarvan onder de titel '1813-1863' een fragment werd afgedrukt in het Album der natuur (1864) 1-5, m. n. 5.

96 Zie over hem in dit verband E. Alkema, 'Het tijdschrift /sis (1872-1881) en de verspreiding van het darwinisme onder het grote publiek', Gewina, IX (1986) 68-91.

97 Brieven van Hartog Heys aan Harting van 30 december 1868, 18 juni 1869,22 juni 1869,29 oktober 1869, HUU; brieven van Harting aan Hartogh Heys, geciteerd in H. F. A. Peypers, 'Levensbericht van Mr. Dr. Herman Hartogh Heys van Zouteveen', Handelingen en mededeelingen van de maatschappij der Nederlandsche letterkunde (Leiden, 1894) 314-368, m. n. 346-348. Aanleiding tot Hartog Heys' voorstel waren Carl Vogts geruchtmakende lezingen over de 'apentheorie' in Rotterdam; zie hierover Hegeman, 'Darwin en onze voorouders', 290-291.

98 J. van der Hoeven, 'De geographische verspreiding der dieren', Album der natuur (1861) 357-375; 'Over de taal en de vergelijkende taalkennis, in verband met de natuurlijke geschiedenis van den mensch', Album der natuur (1862) 80-94; 'De doodsteek aan de leer der doeleinden toegebracht door Darwin', Album der natuur (1864) 308-309. Vg1. Coffeng, 'Het Album der natuur', 59-60.

99 Hegeman, 'Nederlandse reacties', 287-288. 
merendeel 'der thans levende exemplaren van homo sapiens zijn nog kinderen naar den verstande ${ }^{100}$, en

bij het apostelschap der wetenschap behoort derhalve ook menschenkennis en vooral menschenliefde, die ons weerhoudt denkbeelden, die voor de wetenschap volkomen gerechtvaardigd zijn, te midden eener maatschappij te werpen, die daarvoor nog niet rijp is ${ }^{101}$.

Het leek Harting beter - zo liet hij ook Hartogh Heys weten — dat het volk eerst vertrouwd werd gemaakt met een grotere ouderdom van het mensdom dan in de bijbel werd gesuggereerd. Zelf waagde hij zich in het Album aan een 'bloote gissing' van zo'n 20.000 jaar, al benadrukte hij ook hier dat 'behoedzaamheid' geboden bleef ${ }^{102}$.

Maar het lijken niet alleen motieven van pedagogische aard te zijn geweest die hem tot zijn terughoudendheid noopten. Ik zou willen suggereren dat Harting zelf geruime tijd een tegenstelling ervoer tussen zijn wereld- en mensbeeld en de boodschap die de evolutietheorie leek uit te dragen. Toen hij de theorie in 1869 uiteindelijk in het Album ter sprake bracht ${ }^{103}$, was er bij hem een nieuw wereldbeeld uitgekristalliseerd waarin strijd een centrale rol speelde. Hierbij verwees strijd niet meer naar 'moeite doen', maar naar een gevecht op leven en dood. Dat deze ommekeer niet zonder innerlijke beroering tot stand kwam, komt uit het betreffende artikel duidelijk naar voren. Niet alleen staat de sfeertekening die Harting hier van het dierenleven gaf in schril contrast met de vredige tafereeltjes die hij in de jaren vijftig schetste, de toon is voor zijn doen ook ongebruikelijk geladen. Men stelde zich de aarde graag voor als een 'tooneel van geluk', begon hij, 'van liefde en eensgezinsheid harer bewoners'. Maar de werkelijkheid was anders. De aarde was 'een groot slagveld, waarop onophoudelijk de sterkeren de zwakkeren vervolgen, de listigen de onnozelen verschalken en waarop het geluk van den eenen slechts verkregen wordt ten koste van het ongeluk van den anderen ${ }^{\prime 04}$.

Geen vrede heeft de natuur gewild, maar oorlog, geen liefde, maar haat, geen vriendschap, maar vijandschap, geen vreugd, maar lijden, geen leven, maar dood. Voorwaareen somber beeld, zeer verschillend van het liefelijke beeld, waaronder wij ons zoo gaarne de natuur voorstellen ${ }^{105}$.

En dit gold niet alleen voor de dierenwereld maar evengoed voor de mens: 'ook de menschenwereld [geeft ons] veel haat en vijandschap, veel onverdiend lijden, menigen vroegtijdigen dood te aanschouwen' ${ }^{106}$.

Eenzelfde grimmigheid kenmerkt Hartings beschouwing over de Frans-Duitse

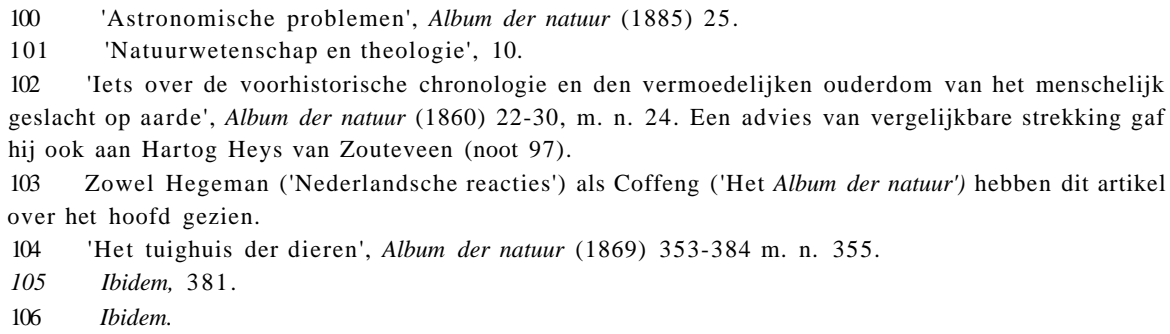


oorlog uit 1870. Zijn geschokte reactie op de oorlog doet vermoeden dat zijn ooit zo rooskleurige mensbeeld er definitief door werd ondermijnd en plaatsmaakte voor een visie die overeenstemde met de bloed-en-tranenmetaforiek die hij aan het evolutionisme verbond: "magt gaat boven regt! ' Het is eenmaal niet anders ... De natuurwetten kennen geen mededoogen'. En: 'Mogen wij ten dien aanzien voor den mensch eene uitzondering maken? Wij weten het beter. Inderdaad is er geen roofdier zoo verslindend als de mensch'107.

Voor een goed begrip moet hierbij worden aangetekend dat Harting het menselijke strijdtoneel niet zag als een gevecht van allen tegen allen of als een klassenstrijd. De strijd ging tussen verschillende menselijke 'typen' of 'rassen', zoals Germanen en Kelten, en in het verlengde hiervan, tussen naties. Uiteindelijk, vermoedde hij, zou de wereld grotendeels door Europese volkeren worden beheerst ${ }^{108}$. Op nationaal niveau bleef Harting - overtuigd of niet, dat valt moeilijk uit te maken — eendracht en saamhorigheid prediken ${ }^{109}$. Verder vond hij een manier om aan de onvermijdelijke struggle for life toch nog een positieve draai te geven. Al moest hij er de moed der wanhoop voor mobiliseren, volksopvoeder bleef hij. Ondanks alle leed en ellende kon er namelijk toch nog van harmonie worden gesproken—al was dit een heel ander soort harmonie dan hij vroeger had aangenomen. Er openbaarde zich in de natuur

een plan, een denkbeeld. En dit denkbeeld is zoo grootsch, zoo verheven, dat alles wat tot zijne verwezenlijking bijdraagt door ons slechts met eerbiedige bewondering kan aangestaard worden. Dit denkbeeld is: de allengs voortgaande vervolkomening der bewerktuigde [i.e. organische] wereld ${ }^{110}$.

107 De strijd des levens, resp. 15 en 9.

108 Ibidem, 14-15.

109 Ook Te Velde (Gemeenschapszin en plichtsbesef, 75) signaleert een groeiende nadruk op 'strijd' onder liberalen, waar eerder harmonie het sleutelwoord was geweest. Tevens stelt hij echter dat het toenmalige Nederlandse liberalisme, met zijn nadruk op gemeenschapszin, niet kon samengaan met sociaal-darwinisme. Wie sociaal-darwinistische ideeën verkondigde, hield volgens Te Velde op een liberaal te zijn. Het voorbeeld van Harting laat zien dat het ingewikkelder ligt. Nog afgezien van het feit dat het vaak moeilijk van negentiende-eeuws 'darwinisme' is te scheiden, was er 'sociaal-darwinisme' in vele soorten en maten. Elke sociaal-politieke richting had bij wijze van spreken zijn eigen variant; zie voor Nederland bijvoorbeeld P. de Rooy, Darwin en de strijd langs vaste lijnen (Nijmegen, 1987). Sociaaldarwinisme hoefde verder niet gepaard te gaan met geloof in bruut geweld. Dit was zelfs meestal niet het geval: zie R. C. Bannister, Social Darwinism. Science and myth in Anglo-American social thought (Philadelphia, 1979); vgl. J. G. Hegeman, 'Het sociaal-darwinisme. Nieuwe en oude literatuur', Theoretische geschiedenis, XII (1985) 127-140. Er hoeft dus ook geen tegenspraak te zijn met de gemeenschapszin van de liberalen. Tenslotte is het belangrijk in het oog te houden waar 'strijd' precies naar verwijst: naar strijd tussen individuen, groepen, rassen of naties. Harting doelde vooral op rastypen en naties, en er is dus geen tegenspraak met zijn liberale overtuigingen. Dat er ook binnen de natie een geweldadige strijd tussen belangengroepen zou kunnen losbarsten, was voor hem mogelijk wel een schrikbeeld dat voedsel gaf aan zijn steeds pessimistischer toekomstverwachting en hem steeds nadrukkelijker op de noodzaak van nationale eendracht deed wijzen.

110 'Het tuighuis der dieren', 381. 
En:

De 'overleving van de geschiktste' geeft hier de sleutel tot verklaring van de wonderlijke harmonie, van die voortreffelijke overeenstemming van middel en doel, die in de geheele schepping heerscht 111.

Harmonie en strijd werden zo, weliswaar elk in een nieuwe betekenis, toch nog met elkaar verenigd.

In tegenspraak met Darwins oorspronkelijke bedoelingen, interpreteerde Harting het evolutieproces dus als een progressief proces dat, weliswaar met dood en verderf als prijs, steeds hogere en betere levensvormen voortbracht. Dit was een interpretatie die Harting met veel tijdgenoten deelde. Het was juist de gelijkstelling van evolutionaire ontwikkeling met vooruitgang, die het evolutionisme voor veel negentiende-eeuwers aanvaardbaar maakte, ook omdat de mens, als hoogtepunt in de ontwikkeling, zo toch nog iets van zijn unieke positie behield ${ }^{112}$. Harting zag het ook zo:

Ontwikkeling, toeneming in volkomenheid naar lighaam en naar geest zijn alleen mogelijk ten koste van strijd en gevaar, gevolgd door inspanning en overwinning. Die les predikt de geschiedenis der menschheid en van de geheele dierenwereld ${ }^{113}$.

Voor pessimisme was dan ook geen aanleiding, want de 'overtuiging, dat het menschelijk geslacht, al is het ook langs een zigzaglijn, allengs hooger stijgt, geeft moed voor de toekomst' ${ }^{114}$. En 'strijd' had zeker ook positieve kanten:

Een volk dat voortleeft in gelijken gedachtengang als waarin zijne voorvaderen zich gelukkig en tevreden gevoelden, is in den strijd om het bestaan, die thans tusschen de natiën gevoerd wordt, tot onvermijdelijken ondergang gedoemd, wanneer het niet met den tijdstroom der beschaving medegaat, maar zich uit liefde voor het oude, waarmede het is opgegroeid, daartegen in een vruchteloos spartelen verzet... Niets is, alles wordt... Wording, ontwikkeling, evolutie, vooruitgang, verbetering, ziedaar de wachtwoorden van onzen tijd $\mathrm{d}^{15}$.

Al met al betekende deze oplossing voor Harting zelf niet dat hij zijn oude optimisme hervond. Zoals gezegd werden zijn laatste levensjaren overschaduwd door crisisgevoel en neerslachtigheid, want op nationaal niveau leek van vooruitgang en verbetering weinig te bespeuren. Zijn in vroegere geschriften zo duidelijk aanwezige religieuze overtuiging begon hem meeren meer te ontvallen. De rol van het geloof leek hem definitief uitgespeeld: 'Het humanisme, dat wij bijna geneigd zouden zijn de religie der toekomst te noemen, moet... den weg wijzen' ${ }^{116}$. In dezelfde richting wijst

111 Johannes Florentinus Martinet', 15.

112 P. Bowler, The invention of progress. The Victorians and the past (Oxford, 1990); Idem, The non-

Darwinian revolution. Reinterpreting a historical myth (Baltimore-Londen, 1988).

113 'Het tuighuis der dieren', 384.

114 'Wetenschap en geloof, 52; zie ook 'Eene psychologische studie naar aanleiding van een hangend vraagstuk', Album der natuur (1874) 161.

115 'Natuurkennis als opvoedingsmiddel' (1885) 393-394, 397.

116 Ibidem, 394. 
zijn opmerking dat zich ook op basis van wetenschappelijke kennis, met name de evolutietheorie, 'eenen zedeleer [laat] opbouwen, even voortreffelijk als de christelijke moraal' ${ }^{117}$. In zijn laatste levensjaar schreef hij in het Album over astronomie en durfde hij het aan het bestaan van een transcendente God ter discussie te stellen. Als het heelal eeuwig was, dan was de aanname van een transcendente God overbodig. Dan resteerde slechts de mogelijkheid van een immanente God, waarvan

het begrip samenvalt met het algemeen arbeidsvermogen dat aan alle stof eigen is. Met andere woorden, dan is er alleen een pantheïstische wereldbeschouwing mogelijk; van werkelijk deïstische voorstellingen kan dan geen sprake meer zijn ${ }^{118}$.

Alleen Hartings geloof in wetenschappelijke kennis als grondslag van de beschaving bleef ongeschonden. In zijn afscheidsbijdrage aan het Album der natuur vatte hij zijn credo aldus samen:

Kennis is macht! Die spreuk moge niet de geheele waarheid zijn, want aan kennis moet zich bij een volk wilskracht, plichtbesef en een volhardend streven naar het ideaal goede voegen ... Toch, al zijn die zedelijke krachten groot en geenszins te minachten, huist de macht van volken en van individuen daar, waar de grootste som van positieve kennis wordt aangetroffen, - want op die kennis berusten alle handelingen, die tot instandhouding van het geheel, tot verdediging tegen vijanden en tot bevordering van het welzijn der staatsburgers strekken ${ }^{119}$.

\section{Epiloog}

Hartings rol als volksopvoeder werd overgenomen door de botanicus Hugo de Vries, die hem in 1885 als redacteur van het Album der natuur opvolgde. De Vries onderschreef Hartings leus dat natuurkennis een doeltreffend 'opvoedingsmiddel' was, en ook hij rekende 'de bevordering van het volksgeluk' tot de taken van de natuuronderzoeker. Maar er zijn ook belangrijke verschillen. Bij De Vries ontbreken van meet af aan verwijzingen naar God of naar de harmonie van de schepping. En in zijn populaire werk lag het accent meer op 'wetenschapsvoorlichting', met speciale aandacht voor het praktisch nut dat nieuwe wetenschappelijke ontdekkingen de maatschappij konden opleveren $^{120}$.

Het ontbreken van fysico-theologische verwijzingen en het genoemde accentverschil illustreren uiteraard de voortgaande professionalisering van de natuurwetenschappen in de negentiende eeuw. Zo bestaat er bij De Vries ook een veel duidelijker scheiding tussen het wetenschappelijke en het maatschappelijke dan bij Halting het geval was. Hartings politieke betrokkenheid ontbreekt bijvoorbeeld bij De Vries ten enen male.

117 'De beteekenis der zoölogie voor de hedendaagse beschaving'. Album der natuur (1882) 23-37, m. n. 13.

118 'Astronomische problemen', Album der natuur (1885) 101-126, m. n. 102.

119 'Natuurkennis als opvoedingsmiddel' (1885) 394.

120 B. Theunissen, 'De beheersing van mutaties. Hugo de Vries' Werdegang van fysioloog tot geneticus', Gewina, XV (1992) 97-1 15;ldem, 'Natuursporten levensgeluk. Hugo de Vries, Eli Heimans, Jac. P. Thijsse', Gewina, XVI (1993) 287-307. Vgl. E. Homburg, 'Van volksscheikunde tot technologie. Popularisering van de chemie in de negentiende eeuw', Gewina, XVIII (1995) 72-101. 
Harting kan aldus worden gezien als een tussenfiguur die elementen combineerde van de oudere, 'geleerde' wetenschapsopvatting, die ook zedelijke verheffing en beschaving nastreefde, en de laat negentiende-eeuwse, 'moderne' visie waarin de autonomie van wetenschappelijke kennisverwerving werd benadrukt.

Betekent dit nu ook dat de geïntegreerde behandeling van het wetenschaps- en maatschappijbeeld van een onderzoeker, zoals ik die hier heb nagestreefd, zijn bruikbaarheid verliest bij de behandeling van de meer geprofessionaliseerde onderzoekers die tegen het eind van de negentiende eeuw aantraden? Alleen al het gegeven dat deze vraag een element van begging the question bevat, is een aanwijzing dat dit niet het geval hoeft te zijn. Immers, dàt onderzoekers naar autonomie streefden en het wetenschappelijke en maatschappelijke steeds scherper van elkaar afgrensden, vraagt op zichzelf al om een verklaring.

Dat het 'Duitse model' in Nederland een belangrijke voorbeeldfunctie had is evident, maar die had het ook voor andere landen. Het Duitse model gaat al te gemakkelijk functioneren als een teleologisch moderniseringsperspectief $m$ disguise, dat meer oog heeft voor overeenkomsten dan voor door de lokale context bepaalde verschillen. Wat een figuur als De Vries precies onder zuivere wetenschap verstond en hoe hij de relatie tussen wetenschap en maatschappij opvatte, vertelt het Duitse model ons niet. Sterker nog, het zet ons in De Vries' geval zelfs op het verkeerde been. Elders heb ik betoogd dat de notie van een scheiding tussen wetenschap en maatschappij in De Vries' geval een belangrijke nuancering behoeft ${ }^{121}$. De Vries verdedigde een kennisideaal dat weliswaar van de autonomie van de onderzoeker uitging, maar dat tevens 'maatschappelijke relevantie' als eis stelde. Voor De Vries was wetenschappelijke kennis de motor van de vooruitgang en diende de onderzoeker zich toe te leggen op de fundamentele analyse van maatschappelijk belangrijke onderwerpen. Zelf gaf hij hieraan vorm door het variëren en muteren van planten te onderzoeken, om zo de mechanismen op het spoor te komen waarmee plantenkwekers de eigenschappen van nutsgewassen naar believen zouden kunnen veranderen ${ }^{122}$. Onderzoek dat niet op een of andere manier bijdroeg aan de 'leniging van maatschappelijke noden en ellende' had voor De Vries zelfs geen bestaansrecht - een opvatting die hij verdedigde vanuit een progressief-liberale, door humanitair besef en scientistisch vooruitgangsgeloof gekenmerkte maatschappijvisie ${ }^{123}$.

Niet alleen voor een figuur als Harting, die aan het begin stond van de professionalisering van de natuurwetenschappen in de negentiende eeuw, maar ook voor latere onderzoekers als De Vries, die gewoonlijk als protagonisten van de 'moderne'

\footnotetext{
121 B. Theunissen, "Knowledge is power'. Hugo de Vries on science, heredity and social progress', British journal for the history of science, XXVII (1994) 291-311.

122 Theunissen, "Knowledge is power"; idem, 'Closing the door on Hugo de Vries' Mendelism', Annals of science, LI (1994) 225-248.

123 Het ideaal van 'toepassingsgericht' wetenschappelijk onderzoek is ook bij andere gezaghebbende Nederlandse natuurwetenschappers terug te vinden; zie B. Theunissen, F. van Lunteren, ed., Zuivere wetenschap en praktische nut. Visies op de maatschappelijke betekenis van wetenschappelijk onderzoek rond 1900(Rotterdam, 1994) (themanummer Gewina, XVII (1994) nr. iii), en B. Theunissen, 'The 'Delft tradition' revisited. M. W. Beijerinck and the genetics of micro-organisms', Journal of the history of biology, ter perse.
} 
wetenschapsopvatting worden gezien, had het begrip wetenschap dus een heel eigen strekking en betekenis. Dergelijke wezenlijke nuances worden pas zichtbaar wanneer de Nederlandse wetenschapsontwikkeling, in de vroege even goed als in de late negentiende eeuw, in haar bredere maatschappelijke context wordt geplaatst. Zo'n benadering verrijkt niet alleen het inzicht in een van de belangrijkste periodes in de Nederlandse wetenschapsgeschiedenis, maar kan naar mijn mening ook een dimensie toevoegen aan de negentiende-eeuwse cultuurgeschiedenis ${ }^{124}$.

124 Met hartelijke dank aan de medewerkers van het Utrechts Universiteitsmuseum, in het bijzonder Bert Smiesing en Steven de Clercq, voor de verleende gastvrijheid en ondersteuning, en aan mijn collega's van het Utrechtse instituut voor geschiedenis der natuurwetenschappen voor hun adviezen en commentaar. 


\section{Restauratie en revolutie. De laatste regeringsjaren van koningin Wilhelmina $^{1}$}

\section{FASSEUR}

\section{Inleiding}

De laatste regeringsjaren van koningin Wilhelmina, tussen de bevrijding van Nederland en haar abdicatie in 1948, worden gekenmerkt door twee allesoverheersende feitencomplexen, de restauratie en wederopbouw van Nederland enerzijds en de Indonesische revolutie anderzijds. Voor Wilhelmina moet dit een even teleurstellende als verrassende ontknoping van haar lange regering zijn geweest. Zij had zich immers in de oorlog een vurig voorstander getoond van een na de bevrijding radicaal vernieuwd Nederland. Van die radicale vernieuwing kwam na 1945 echter weinig terecht. Voor het denkbeeld van een gewijzigde grondwet en een sterk koninklijk bewind, dat zijn legitimatie zou ontlenen aan de gebundelde krachten van de vroegere illegale strijders, het 'heldenvolk' waarnaar de koningin zo graag in haar oorlogstoespraken had verwezen, bleek in de na-oorlogse constellatie geen voldoende steun te vinden. Reeds spoedig, in feite al bij het aantreden van het kabinet SchermerhornDrees op 24 juni 1945, ook al noemde zich dit een nationaal kabinet van herstel en vernieuwing, kon die illusie worden begraven. De Tweede Kamerverkiezingen van mei 1946 bewezen de taaie kracht van de vooroorlogse politieke partijen en verhoudingen. Het kabinet-Beel, dat op 3 juli 1946 het roer in handen nam, wilde geen staatkundige experimenten. In haar drie weken later, op 23 juli 1946, voor het nieuwe parlement uitgesproken troonrede restte de koningin weinig anders dan haar voldoening uit te spreken over deze 'terugkeer tot normale grondwettelijke vormen en stabiele staatkundige verhoudingen' ${ }^{2}$. Ten aanzien van Indonesië lag het in de bedoeling, zoals de koningin dit in haar bekende Londense radiorede van 7 december 1942 had aangegeven, dat de na-oorlogse ontwikkeling zich heel wat geleidelijker zou voltrekken. Weliswaar in de richting van staatkundige ontvoogding, onder erkenning van het beginsel van de interne autonomie van de overzeese gebiedsdelen, maar dan toch met behoud van de koninkrijksband. In die benadering was wel plaats voor een zelfstandig, maar niet voor een onafhankelijk Indonesië, en zeker niet voor een onafhankelijkheid die langs revolutionaire weg was bevochten in plaats van uit Nederlandse handen verkregen. Ook hier bleek de uitkomst echter tegengesteld aan haar tijdens de oorlog gekoesterde verwachtingen. Hoe heeft Wilhelmina haar inzichten en idealen na de bevrijding aan de werkelijkheid, waarmee ze zich geconfronteerd zag, aangepast of niet aangepast? Hoe is uiteindelijk haar eindoordeel geweest?

1 Ik dank mevrouw O. Nooy van der Kolff-Tellegen (Uddel), mevrouw G. M. Keijzer-Baldé (Kabinet der Koningin) en de heer M. Baertl (Algemeen Rijksarchief) voor hun vriendelijke medewerking bij het te mijner beschikking stellen van onder hen berustende archiefbescheiden.

2 Keesings historisch archief, 6813 A. 